\title{
異なる照明光下における白色知覚に関する検討
}

\author{
正会員太田 亜紀子（日立物流帅的株式会社） 専門会員 金谷 末子 (金沢工業大学) \\ 専門会員 阿山 みよし（宇都宮大学）正会員 向 健二（松下電器産業株式会社）
}

\section{Perceived Whiteness under Different Lighting Conditions}

Member Akiko Oota (Hitachi Distribution Software Corporation), Fellow Member Sueko Kanaya (Kanazawa Institute of Technology), Fellow Member Miyoshi Ayama (Utsunomiya University), and Member Kenji Mukai (Matsushita Electric Industrial Co., Ltd.)

\begin{abstract}
Many white and/or nearly white objects are in our living and working areas, such as documents written on white paper, white curtains, white clothes, and white walls and furniture. The perceived whiteness of these objects is important to the impression of lighting in these areas. To investigate the perceived whiteness in living areas, a series of experiments were conducted using four different fluorescent lamps in three different environmental conditions.

It was found that the areas of perceived whiteness in the living areas were larger than the areas of perceived whiteness under achromatic conditions. Based on the results of these results, a perceived whiteness index is proposed for these experimental conditions.
\end{abstract}

KEYWORDS : $\quad$ whiteness area, fluorescent lamp, color temperature, achromatic room, living room

\section{1.はじめに}

白紙や白布などの蛍光性を有する白い物体色をより白く見せる ための評価, 白さの度合いを定量的に評価する方法や白色知覚に 関する研究は, 1930 年代から現在に至るまで数多く行われており, 既に，CIE 白色度式や JISZ8715 が制定されている ${ }^{12) 3)}$ ．白色度表 示方法研究委員会（日本色彩学会）では $\mathrm{D}_{65}$ 用蛍光ランプを照明用 光源とし, 白紙や白布を対象に多数の専門家による視感評価実験を 行い, CIE が勧告している CIE 白色度式の適用制限内の試料に対し ては, CIE 白色度が知覚的白さとほぼ対応することを明らかにして いる4).

鈴木らは，光源色の白色度の定量化，相関色温度 $6500 \mathrm{~K}$ 近傍の 数種類の昼光色蛍光ランプを用いた主観評価実験に基づく光源色 の白色度式の提案, 相関色温度 $5000 \mathrm{~K}$ の色評価用高演色性蛍光ラン プの照明光下で写真用カラーペーパーを観察し, その知覚的白さ の定量化などを提案している ${ }^{5) 677)}$.

いっぽう，わが国では居住空間の主光源として蛍光ランプが広 く普及している. 近年, 照明メーカー各社から数多くの蛍光ランプ が市販されるようになり，居住空間でも相関色温度が異なる多種 類の蛍光ランプが用いられるようになってきている.また, 現代建 築における居住空間の内装色は, 従来の伝統的な日本建築のそれ に比べて各面の反射率が高くなる傾向にあり，内装材や物体色な どに白色または白色に近似した色が数多く用いられるようになっ てきている.これらの色の見え方は, 使用する光源の分光特性, 周 辺環境などにより異なる.
また，室内にある白い物体が黄ばんで見えると，室内を暗く 感じるなど, 白色または白色に近似した色の見えは, 空間の明 るさ知覚にも影響すると考えられる. このため, 使用する光源 によって内装色などに用いられる白色または白色に近似した色 の白色知覚がどのように変化するのかを明らかにすることは, 居住空間における光源や内装材の選定をする上で重要であると 考えられる.

片山らは, 各種照明光のもとでの白色サンプルの白さを評価 し, 照明光の分光組成が白色物体の知覚白色度に及ぼす影響を 明らかにしている ${ }^{879)}$. 赤津らの先行研究では, 居住空間に存在 する白色あるいは白色に近似した 12 種類の色票を用いて白色感 に関する実験を行い, 相関色温度が低くなるにつれて白色感が低 下寸る色票と上昇する色票に分類されることを明らかにした 10) 11) 12) 13). 江田らは, 電球色及び昼光色蛍光灯照明下にお打る知 覚的白色領域について検討した ${ }^{14)}$.しかし,これまでに白色また は白色に近似した色に関する評価指標は明らかにされていない.

そこで, 本報では, 居住空間における白色知覚を明らかにす ることを目的として, 種々の照明光のもとでの白色または白色 に近似した色票を用いて白色知覚の実験を行い, 実験結果を基 に, 白色知覚の定量化について試みることにした。

\section{2. 各種照明光のもとでの白色知覚に関する実験}

ほぼ全色相にわたる高明度（V=9.0〜9.25），低彩度（C=0.5〜 1.5)の 81 枚と N9. $0, N 9.25, N 9.5$ を含む 84 枚の色票を分光特性 の異なる蛍光ランプを用いて照明し, これらの色票の白色知覚 
が光源の分光特性によってどのように変化するかを，無彩色背景条 件（実験 1 ）および有彩色背景条件（実験 2）のもとでそれぞれ実 験した.

\section{1 実験 1 ：無彩色背景下における白色知覚に関する実験 \\ 一㹧帯域発光形蛍光ランプと広帯域発光形蛍光ランプによる 白色知覚の比較}

わが国で狭帯域発光形蛍光ランプである 3 波長域発光形蛍光ラン プが開発されて 20 有余年, 現在では, 住宅をはじめ, 様々な居住 空間で広く普及してきた。狭帯域発光形蛍光ランプは, 従来の広 帯域発光形蛍光ランプに比較して透き通ったような清潔感のある 色の見元や, 白紙や陶磁器の白さを際立たせる特徴のある蛍光 ンプであるが，定量的な検討は行われてこなかった。

\subsection{1 実験条件}

実験には, 相関色温度 $3000 \mathrm{~K}$ と $6700 \mathrm{~K}$ の狭帯域発光形蛍光ランプ と相関色温度 $3000 \mathrm{~K}$ と $6500 \mathrm{~K}$ の広帯域発光形蛍光ランプの 4 種類を 用いた．提示色票は，マンセルバリューが 9.25 でほぼ全色相にわ たる $\mathrm{C}=0.5 \sim 1.5$ の色票 33 枚, マンセルバリューが 9.0 でほぼ全色 相にわたる C=0. 5〜1.5 の色票 48 枚と, N9. 5, N9. 25, N9. 0 の色票, 計 84 枚を用いた. 図 1 に実験に用いた色票の HV/C を示す.

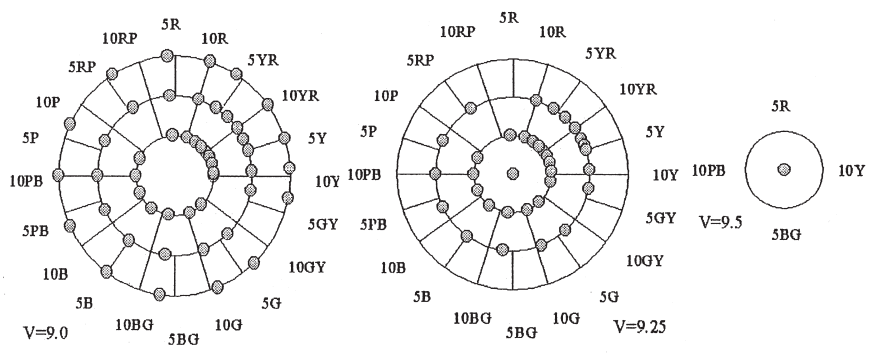

図 1 実験に用いた提示色票の HV $/ \mathrm{C}$

Fig.1 The 84 munsell color sheets used in the experiment.

実験室は予備順応ブースと観察ブースに分け, 両ブース共, 幅 $1.5 \mathrm{~m}$, 奥行き $1.8 \mathrm{~m}$, 天井高さ $1.8 \mathrm{~m}$ で, 内部の壁面は $\mathrm{N} 8$ の布貼り とし，ブース中央に N5 のテーブルクロスをかけたテーブルを配置 した．テーブル面の水平面照度は $5001 \mathrm{x}$ に設定した．観察ブースに は上記の 4 種類の営光ランプを，予備順応ブースにはR, G, B の単色 蛍光体を塗布した蛍光ランプを取り付けた。両ブースの天井には 乳白色拡散パネルを用いて天井全面を光天井とした．被験者は若 年齢者 5 名とした.

\subsection{2 実験手順}

実験に先立ち, 被験者が観察ブースの照明光の色温度を察知で きないように, ランダムに設定した色光の予備順応ブースに被験 者を入室させ, 約 10 分間色順応させた. 10 分間の色順応の後, 被 験者を観察ブースに移動させ, 観察ブースで約 5 分間予備順応さ せた，その後，テーブル脇に置いた箱から 84 枚の色票を無作為に

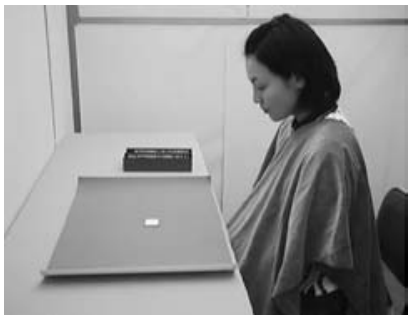

図 2 実験状況

Fig.2 Experimental set-up in which an observer is observing a colour sheet on the table.
1 枚ずつ取出してテーブルの上に置き,「白と感じる色票」か「白 と感じない色票」かのいずれかに分類させた．図 2 に実験状況を 示す. 実験の繰り返し回数は, 各被験者共, 5 回とした.

\subsection{3 実験結果}

図 3 に相関色温度 $3000 \mathrm{~K}$ の狭帯域発光形蛍光ランプと広帯域発 光形蛍光ランプの実験結果を示す. 横軸は提示色票の色相, 縦 軸は抽出回数を示す. 図 3 に示すように, 狭帯域発光形蛍光ラン プの照明光のほうが広帯域発光形蛍光ランプの照明光に比べて 白色と評価する色票数が多く，度数の検定である $\mathrm{t}$ 検定 $(5 \%$ 有 意水準）を行なった結果, 有意差があることが明らかになった. 色相別にみると, $\mathrm{PB}$ 系と B 系の色相を多く抽出した. 図 4 に相関 色温度 $6500 \mathrm{~K}$ の狭帯域発光形蛍光ランプと広帯域発光形蛍光ラン プの実験結果を示す．図 4 から, 狭帯域発光形蛍光ランプと広帯 域発光形蛍光ランプの照明光のもとでの白色として抽出した色 票は, 広帯域発光形蛍光ランプのほうが多かった. 度数の検定 である $\mathrm{t}$ 検定を行なった結果, 有意差があることが明らかになっ た.また，抽出した色相は, $3000 \mathrm{~K}$ と同様に, PB 系, B 系の色相が 他の色相に比べて多かった．また, N系の色相が多く抽出された. 相関色温度の違いによる抽出色相を比較すると， $3000 \mathrm{~K}$ では $\mathrm{PB}$ 系と B 系の色相を集中的に抽出しているのに対して，6500K では $\mathrm{R}$ 系, $\mathrm{YR}$ 系の色相も抽出しており，6500K の場合は，抽出する色 相の範囲が広がっていることが明らかとなった.

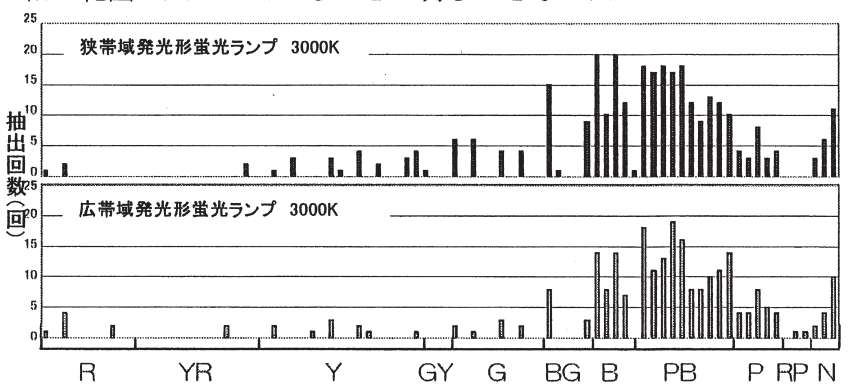

図 3 実験結果（相関色温度 $3000 K$ の場合）

Fig.3 Whiteness evaluation values of the 84 munsell color sheets in the achromatic room under the narrow bands fluorescent lamps, (of which correlated colour temperatures is $3000 \mathrm{~K}$ ) and the broard band fluorescent lamps.

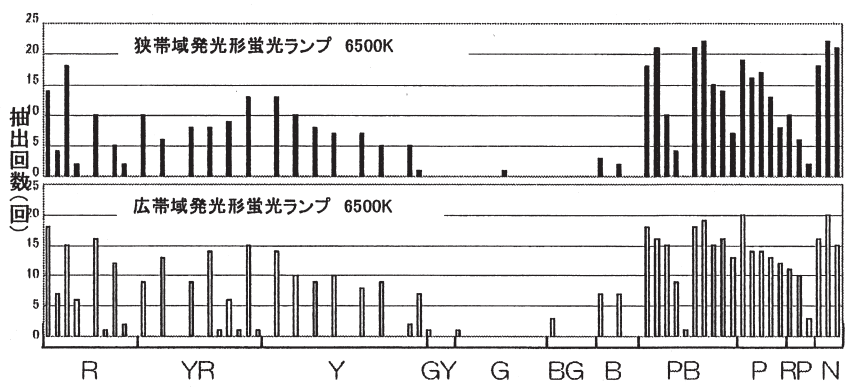

図 4 実験結果（相関色温度 $6500 \mathrm{~K}$ の場合）

Fig.4 Whiteness evaluation values of the 84 munsell color sheets in the achromatic room under the narrow bands fluorescent lamps, (of which correlated colour temperatures is $6500 \mathrm{~K})$ and the broard band fluorescent lamps.

\section{2 実験 2 : 実空間における有彩色背景下での白色知覚}

実際の居住空間では, 複雑で不均一な有彩色背景で白色ある いは白色に近似した色彩を見ている，そこで，実験 2 では，実際 の居住空間の環境下で, 相関色温度の異なる狭帯域発光形蛍光 ランプで照明した白色あるいは白色に近似した色票の白色知覚 
について評価した.

\subsection{1 実験条件}

実験には，白色を基調色とした内装のリビング空間（約 $17 \mathrm{~m}^{2}$ ) と和室 (約 $10 \mathrm{~m}^{2}$ ) を実験に用いた. 照明器具は各室共, 天井中央 に乳白グローブ付直付け照明器具を取り付けた. 光源の種類は, 相 関色温度 $3000 \mathrm{~K}, 6700 \mathrm{~K}$ の 3 波長域発光形蛍光ランプとした. テー ブル面の水平面照度は $5001 \mathrm{x}$ に設定した. 実験 1 では, 単一の無彩 色背景としてN5 の背景を用いたが, 実験 2 では, 複雑で不均一な 有彩色背景を用いた. 有彩色背景には, 住宅メーカー数社のモデル ハウスの資料から住宅内装色としてモダンなリビングルームと和

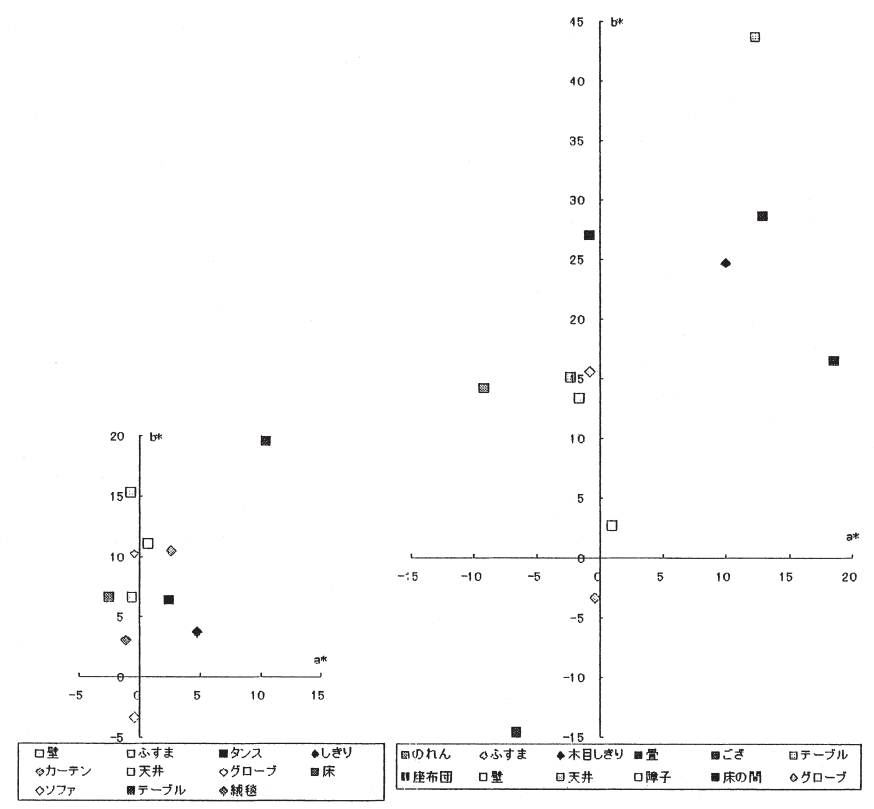

(a) リビング空間

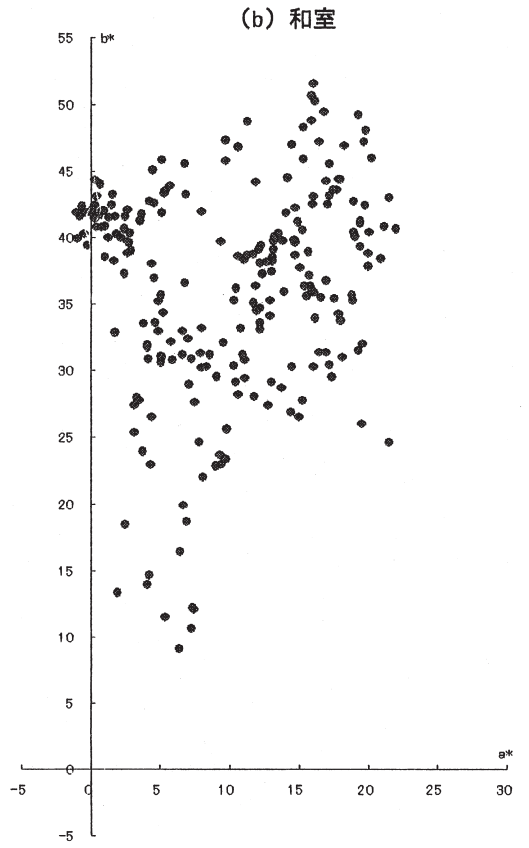

(c) リビング背景シート

(d) 和室背量シート

図 5 リビング空間と和室, 背最として用いた有彩色背景シートの色度值

Fig.5 Chromaticities of colour chips under different fluorescent lamps in living areas and Japanese style living areas were plotted on the CIE1976L*a*b* chromaticity diagram.
室を選定し，それぞれの写真を 315 チップにモザイク処理してカ ラー印刷した．各チップの分光反射率を測定し，それぞれの有彩 色背景の色度座標を算出した。 図 5 (a) (b) (c) (d) に, リビング空 間と和室, および背景として用いた 2 種類の有彩色背景の各チッ プの CIE1976L*a $* \mathrm{~b} *$ 表色系の $\mathrm{a} * \mathrm{~b} *$ 座標の值を示す．また，図 6 に 実験状況を示す．被験者は実験 1 と同一の若年齢者 5 名とした.

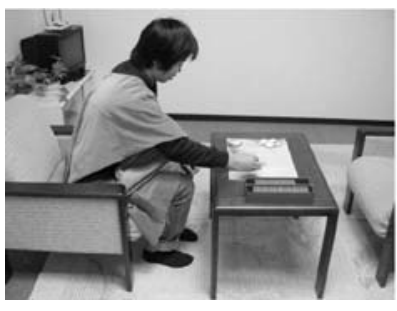

(a) リビング空間

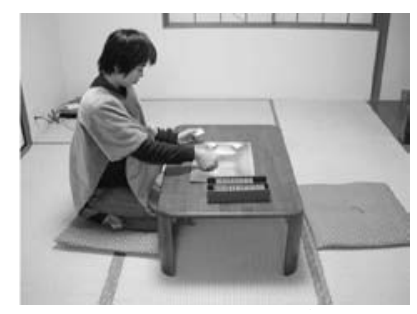

(b) 和室
図 6 実験状況

Fig.6 A typical experimental scene.

\section{2.2 実験手順}

被験者をリビング空間または和室に入室させ, 約 10 分間色順 応させた。その後の実験手順は, 実験 1 と同様であった。繰り返 し回数は 5 回とした.

\subsection{3 実験結果}

図 7 に相関色温度 $3000 \mathrm{~K}$ の蛍光ランプ照明光のもとでのリビン グ空間と和室の実験結果を示す。横軸は色票の種類を色相別に示 し, 縦軸は抽出回数を示す. リビング空間での抽出回数と和室で の抽出回数の結果を度数の検定である $\mathrm{t}$ 検定 ( 5 \% 有意水淮) し た結果, 有意差があることが明らかになった. 色相別にみると, $\mathrm{PB}$ 系と $\mathrm{P}$ 系と $\mathrm{N}$ 系の色相が多く抽出された.

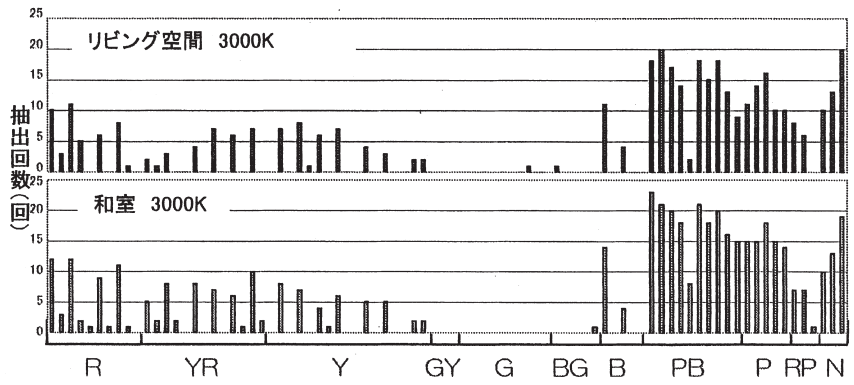

図 7 実験結果（相関色温度 $3000 K$ の場合）

Fig.7 Whiteness evaluation values of the 84 munsell color sheets in the Living room and Japanese room under the fluorescent lamp with the correlated color temperature of $3000 \mathrm{~K}$.

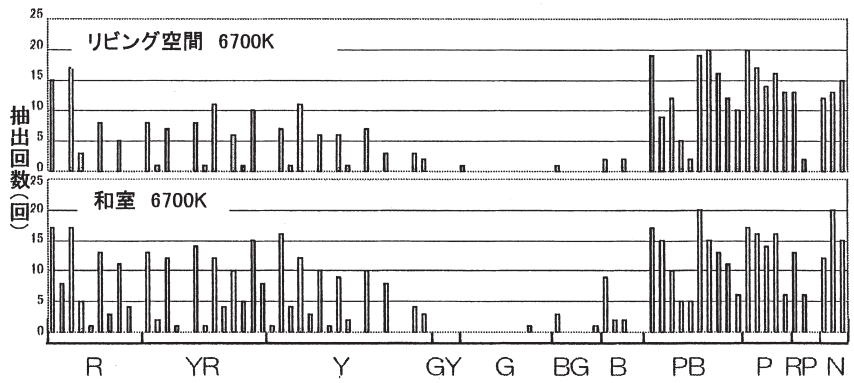

図 8 実験結果（相関色温度 $6700 K$ の場合）

Fig. 8 Whiteness evaluation values of the 84 munsell color sheets in the Living room and Japanese room under the fluorescent lamp with the correlated color temperature of $6700 \mathrm{~K}$. 
図 8 に相関色温度 $6700 \mathrm{~K}$ の営光ランプ照明光のもとでのリビング 空間と和室の実験結果を示す. 同様に, 両者の度数の検定である $\mathrm{t}$ 検定を行なった結果，有意差があることが明らかになった。

\section{3. 実験結果の比較}

無彩色背景で行った実験 1 の結果と有彩色背景で行なった実験 2 の結果を比較した. 図 9, 図 10 に実験結果を示寸. 相関色温度 $3000 \mathrm{~K}$ の場合, 無彩色背景, 有彩色背景共に, $\mathrm{PB}$ 系, $\mathrm{P}$ 系, $\mathrm{N}$ 系の色相を 多く抽出した. 抽出色相の種類は, 無彩色背景に比べて有彩色背景 の方が多くなった．度数の検定である $\mathrm{t}$ 検定の結果, リビング空間 と無彩色背景間には有意差はないが, 和室とリビング空間および 和室と無彩色背景間は有意差があることが分かった。

相関色温度 $6700 \mathrm{~K}$ の場合は無彩色背景, 有彩色背景共に, PB 系 $\mathrm{P}$ 系 $\mathrm{N}$ 系 $\mathrm{R}$ 系の色相を多く抽出している. 度数の検定である $\mathrm{t}$ 検定の 結果, リビング空間と無彩色背景間には有意差はないが，和室と リビング空間および和室と無彩色背景間は有意差があることが分 かった.

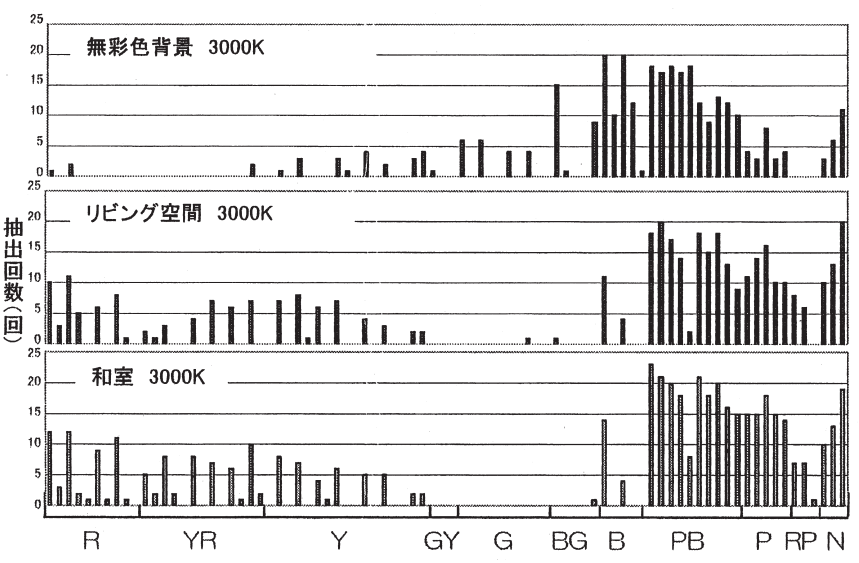

図 9 実験結果の比較（相関色温度 3000K の場合）

Fig.9 Whiteness evaluation values of the 84 munsell color sheets in the achromatic room and Living room and Japanese room under the fluorescent lamp with the correlated color temperature of 3000K.

年色景 6500K

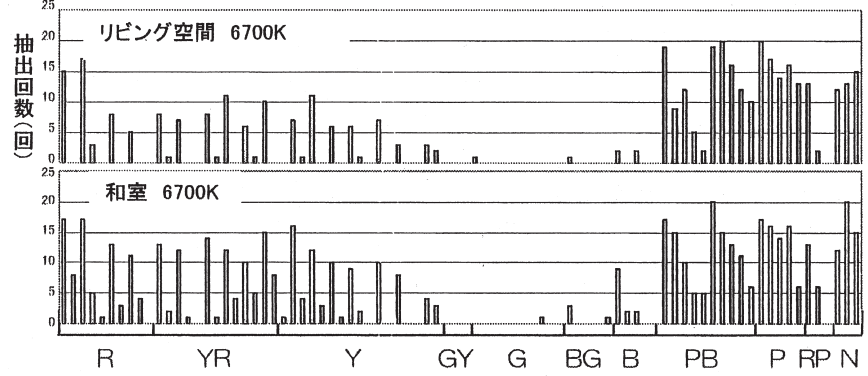

図 10 実験結果の比較（相関色温度 $6700 \mathrm{~K}$ の場合）

Fig.10 Whiteness evaluation values of the 84 munsell color sheets in the achromatic room and Living room and Japanese room under the fluorescent lamp with the correlated color temperature of $6700 \mathrm{~K}$.

\section{4. 実験結果と色知覚属性値との対応}

前述したように, 1986 年に CIE 白色度指数が勧告され，これを基
にJIS8715 が制定された. また, 種々の照明光のもとでの物体色 の見えを予測する色の見えモデルについては, 多くの研究が行な われ, CIE では 1997 年に CIECAM97s が提案され, 色知覚属性值が 定められている. そこで, 今回行なった実験結果と, 白色度指 数およびCIECAM97s で定められている色知覚属性值との対応につ いて検討した.

図 11 (a) に実験 1 の相関色温度 $3000 \mathrm{~K}$ の場合の抽出回数と白色 度指数の対応関係を, 図 11 (b) に実験 1 の相関色温度 $6500 \mathrm{~K}$ の場 合の抽出回数と白色度指数の対応関係をそれぞれ示す. 図 11 (a) (b) に示すように, 抽出回数と白色度指数との間の相関係数は相 関色温度 $3000 \mathrm{~K}$ の場合は 0.60 , 相関色温度 $6500 \mathrm{~K}$ の場合は 0.30 となり，いずれも相関性が低いことが分かった。

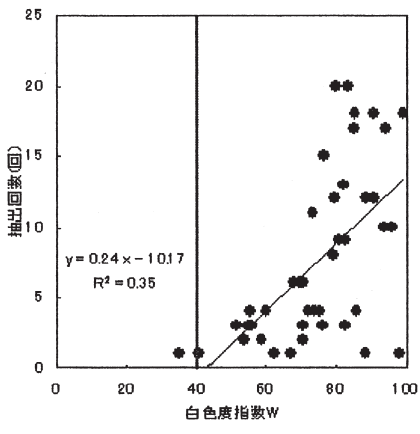

(a) 相関色温度 $3000 K$ の場合

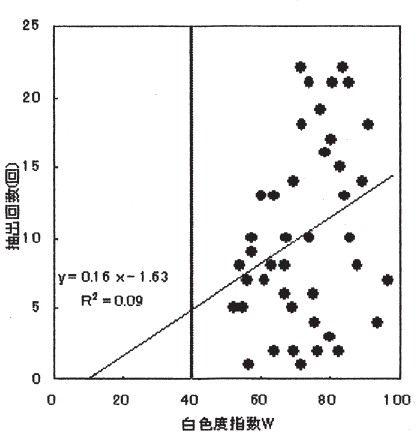

(b) 相関色温度 $6500 K$ の場合
図 11 無彩色背景の場合の抽出回数と白色度指数との対応

Fig.11 Correction between the experimental result and $\mathrm{CIE}$ whiteness index $\mathrm{W}$ in the achromatic room.

前述したように, 向らは赤津らの主観評価実験結果を基に CIECAM97s の色知覚属性の一つであるクロマC との対応について 検討し, クロマ $\mathrm{C}$ と主観評価結果との間には, 相関係数 -0.93 の 高い負の相関があることを明らかにしている，赤津らの主観評 価実験では 7 種類の色票に限られているが, 今回の実験では, ほ ぼ全色相にわたる 84 枚の白色または白色に近似した色票を用い ている，そこで，今回の実験結果とクロマCとの対応関係につい て検討した.

図 12 (a) (b) に相関色温度 $3000 \mathrm{~K}$ と相関色温度 $6500 \mathrm{~K}$ での無彩色 背景の抽出回数とクロマ C との対応を示す. 図 12 (a) (b) に示す ように, 相関色温度 $3000 \mathrm{~K}$ の場合の相関係数は-0.85, 相関色温 度 $6500 \mathrm{~K}$ の場合は-0.60 となった。

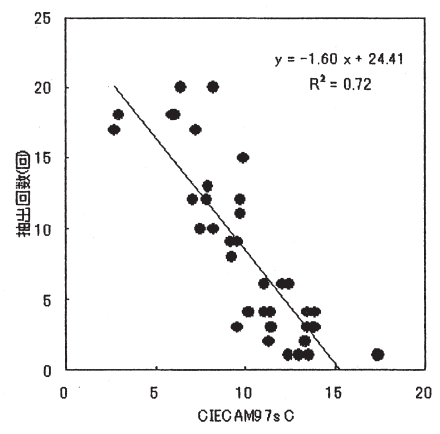

(a) 相関色温度 $3000 K$ の場合

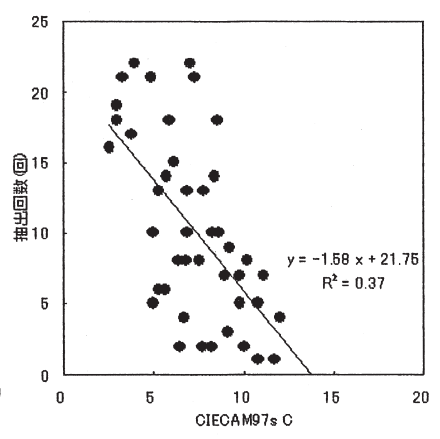

(b) 相関色温度 $6500 K$ の場合
図 12 無彩色背景の場合の抽出回数と CIECAM97s C との対応

Fig.12 Correction between the experimental result and the modified CIECAM97s chroma C in the achromatic room. 
また，表 1 に，実験 1 と実験 2 の白色の抽出回数と色知覚属性值の 相関係数を示す. 表 1 に示すように, 抽出回数とクロマCの相関係 数は, 向らが示した相関係数よりは低いが, 両者間には負の相関 があることが分かった。 また， a, b で表される中心座標からの距離 との相関係数は, $-0.57 〜-0.78$ であることが分かった.

\section{表 1 主観評価結果と色知賞属性値の相関係数 \\ Table 1 Correction between the experimental result and the CIE whiteness index W, the modified CIECAM97s C,s,a,b in the achromatic room.}

\begin{tabular}{|c|c|c|c|c|c|c|c|}
\hline & \multicolumn{2}{|c|}{ 無彩色背景 } & \multicolumn{2}{|c|}{ リビング空間 } & \multicolumn{2}{|c|}{ 和室 } \\
\hline & & $3000 \mathrm{~K}$ & $6500 \mathrm{~K}$ & $3000 \mathrm{~K}$ & $6700 \mathrm{~K}$ & $3000 \mathrm{~K}$ & $6700 \mathrm{~K}$ \\
\hline $\begin{array}{c}\text { 白色度 } \\
\text { 指数 }\end{array}$ & W & 0.60 & 0.30 & 0.54 & 0.47 & 0.68 & 0.35 \\
\hline \multirow[b]{3}{*}{ CIECAM97s } & 加 $\mathrm{C}$ & -0.85 & -0.60 & -0.57 & -0.68 & -0.74 & -0.78 \\
\hline & 飽和度 s & -0.84 & -0.60 & -0.60 & -0.66 & -0.76 & -0.77 \\
\hline & $\begin{array}{l}\text { ab で表され } \\
\text { る中心座標 } \\
\text { からの距離 }\end{array}$ & -0.78 & -0.64 & -0.57 & -0.76 & -0.74 & -0.77 \\
\hline
\end{tabular}

\section{5. 白色知覚の定量化への試み}

\section{1 白の許容率と等白色許容率軌跡の算出}

実験 1 と実験 2 では, 84 枚の色票をそれぞれの照明条件のもとで 観察し,「白と感じる色票」または「白と感じない色票」に分類さ せた．言い換えれば，提示される色票を白として許容できるか否 かを判定させたことになる.

既述したように，鈴木らはCIE1976L*a*b*表色系の a*b*座標上で 第 3 象限と第 4 象限に分布する 44 枚の写真用カラーペーパーを色 評価用高演色性蛍光ランプ（相関色温度 5000K）で照明し，それら の心理的白さを求めた実験から白色度式を提案している。一方, 本実験で用いた提示色票の測色值は第 1 象限から第 4 象限までの広 範囲に分布する色票を用いている.

居住空間における白色知覚について検討することを目的とした 本研究では, 全色相にわたる高明度, 低彩度の色票を用いて一般 照明で使用されている相関色温度が異なる蛍光ランプを用いて実 験を行った. したがって，使用光源や提示色票が異なる鈴木らの 結果と直接比較することはできないが，白色領域にどのような差 異があるかを検討することとした

実験 1 と実験 2 の実験結果に対して統計的に有意な水準であると みなされる許容率を有意水準 $5 \%$ として $x^{2}$ 分布を用いて算出した. まず, 実験 1 の結果について $x^{2}$ 分布で求めた各照明条件の結果 を, 明らかに白として許容されるのは $72 \%$ 以上の確率のもの, 明 らかに白ではないと判断されるのは $28 \%$ 以下の確率のもの, どち らでもないと判断されるのは $28 \%$ 7 $72 \%$ の確率の 3 グループに分 類した. 図 13 (a) (b)に相関色温度 3000K，6500K（いずれも狭帯域 発光形蛍光ランプ）の各色票の白の許容率の分布を CIE1976L*a*b* 表色系 $\mathrm{a} * \mathrm{~b} *$ 座標上に示す，ここで，の印は白としての許容率が $72 \%$ 以上，印印は白としての許容率が $28 \%$ 72\%，×印は白とし ての許容率が $28 \%$ 以下の色票を示す.

次に, 白の許容率から等白色許容率の軌跡を求めた。 中心座標 は各照明条件のもとで「白」と「どちらでもない」と許容された色 票の平均值とした。長軸は各色票の測色值 $\mathrm{a} * \mathrm{~b} *$ 值を用いて主成分 分析を行い, 固有值と固有ベクトルを求め, 第 1 主成分を算出し た。第 1 主成分から傾斜角を求め, 中心座標を通る直線を求め, これを長軸とした，短軸は，長軸と垂直に交わり，中心座標を通 る直線とした，等白色許容率軌跡は, 以下に示寸楕円 (2 次曲線) の 式を用いて算出した．楕円の式には求める定数 $\mathrm{b}, \mathrm{c}, \mathrm{d}$ があり，この

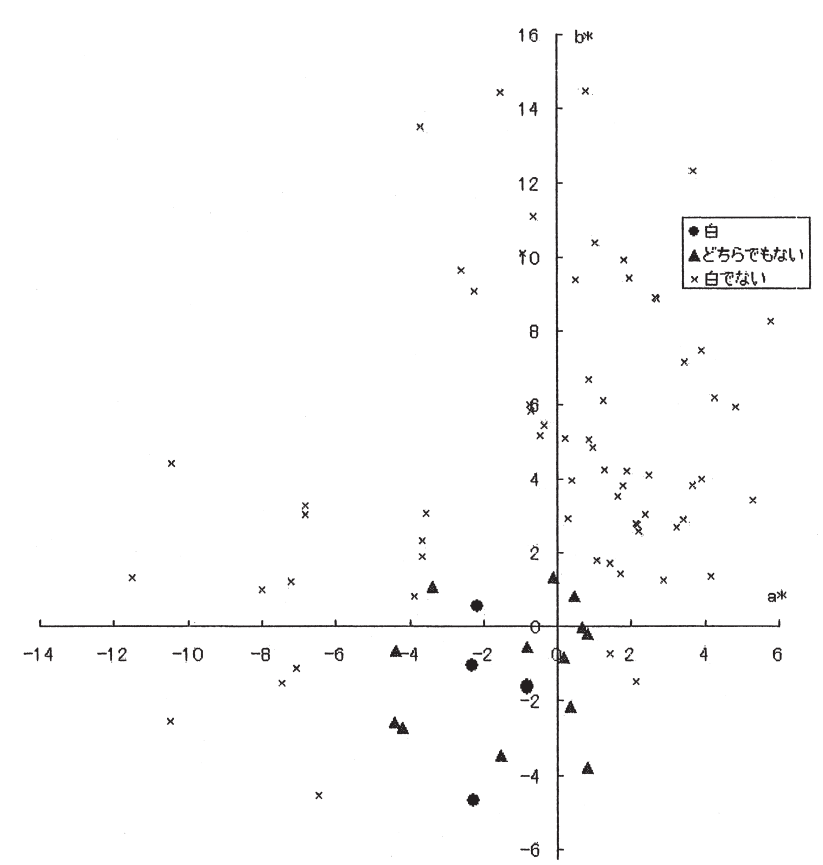

(a) 相関色温度 $3000 \mathrm{~K}$

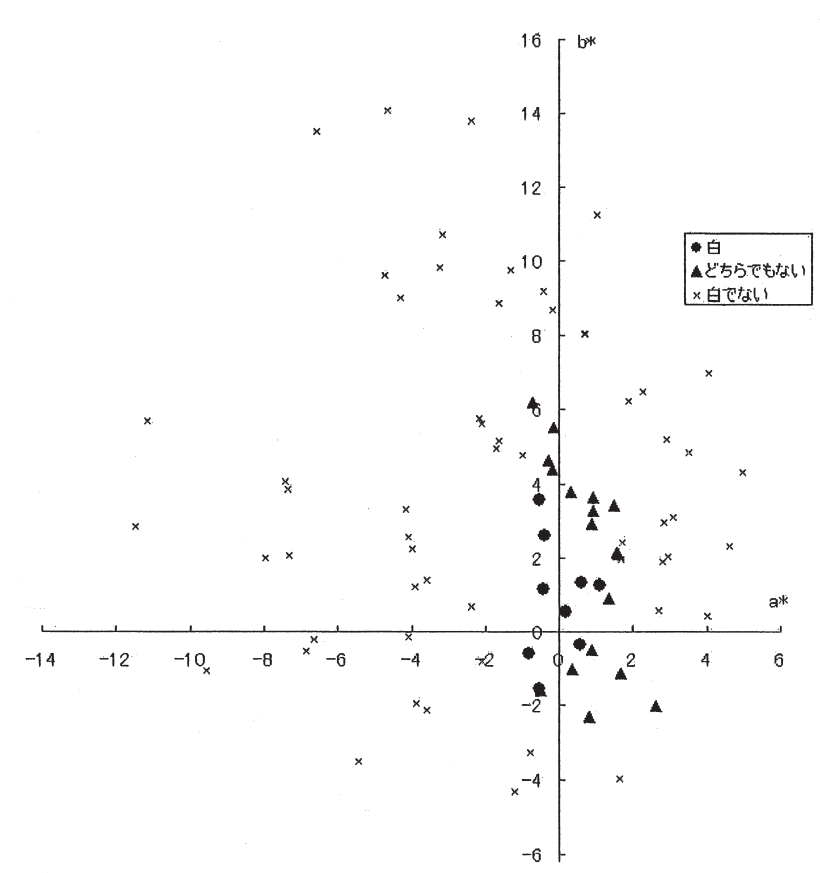

(b) 相関色温度 $6500 \mathrm{~K}$

図 13 各色票の白の許容率の分布

Fig.13 The distribution of permissible rate to the perceptual whiteness in the achromatic room under the fluorescent lamp with the correlated color temperature of $3000 \mathrm{~K}$.

定数を決定させるために通る点を 3 点設定した，通る点 3 点は， 長軸座標が最大で短軸座標が最小の点を 1 点とし, その点を中心 O一に関して対称にした点, または, 長軸に関して線対称な点 を 1 点とした。. また, 他の 1 点は短軸座標が最大で長軸座標が 最小の点を 1 点とした. 図 14 (a) (b) に相関色温度 $3000 \mathrm{~K}, 6500 \mathrm{~K}$ （狭帯域発光形蛍光ランプ）の等白色許容率軌跡を示す. 


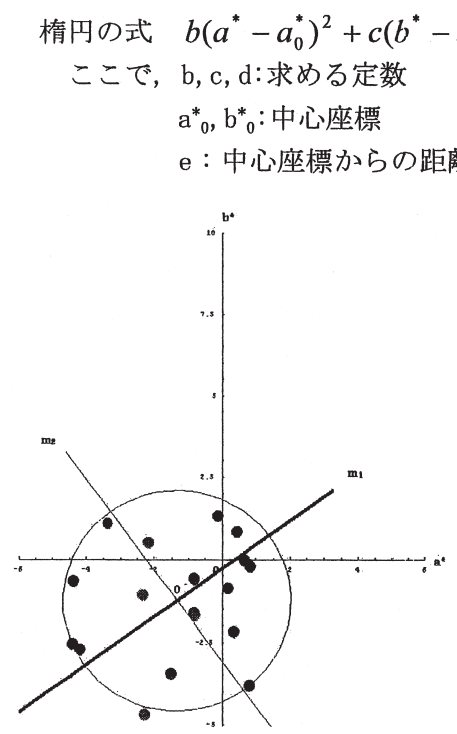

(a) 相関色温度 $3000 \mathrm{~K}$

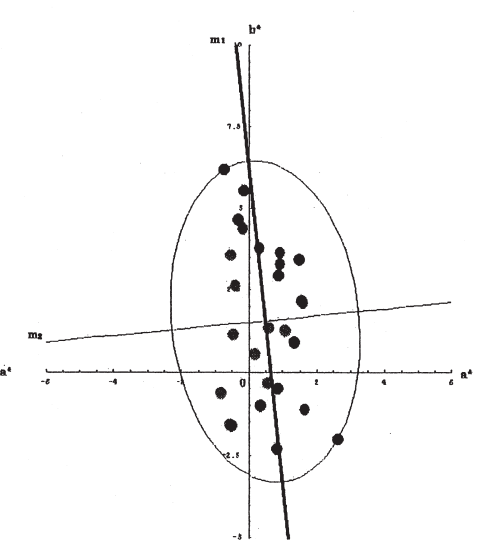

(b) 相関色温度 $6500 \mathrm{~K}$

\section{図 14 等白色許容率軌跡}

Fig.14 The Locus of the equal perceptual whiteness rate in the achromatic room.

次に，実験 2 についても同様の手順で分析した。 図 15 (a) (b)に 相関色温度 $3000 \mathrm{~K}$ (狭帯域発光形蛍光ランプ）の照明光のもとでの リビング空間と和室での白の許容率を, 図 16 (a) (b) に相関色温度 6700K（狭帯域発光形蛍光ランプ）の照明光のもとでのリビング空 間と和室での白の許容率をそれぞれ CIE1976L*a*b*表色系のa*b* 座標上に示す.

実験 1 の場合と同様の手順で, 図 15 (a) (b), 図 16(a) (b)に示し た白の許容率から等白色許容率軌跡を求めた。 図 $17(\mathrm{a})(\mathrm{b})$ に相関 色温度 $3000 \mathrm{~K}$ の照明光のもとでのリビング空間と和室の等白色許容 率軌跡を, 図 18 (a) (b)に相関色温度 $6700 \mathrm{~K}$ の照明光のもとでのリ ビング空間と和室の等白色許容率軌跡をそれぞれ示す.

図 $14(\mathrm{a})(\mathrm{b})$, 図 $17(\mathrm{a})(\mathrm{b})$, 図 $18(\mathrm{a})(\mathrm{b})$ に示したように, 相関色 温度 $3000 \mathrm{~K}$ と相関色温度 $6700 \mathrm{~K}$ の各照明条件下の等白色許容率軌跡 は,ほぼ楕円形状となる。また，これらの等白色許容率軌跡の中心 座標值を比較すると, 無彩色背景の相関色温度 $3000 \mathrm{~K}$ の場合を除い て, 中心座標は第 1 象限で a*准が 1 から 3 , b*值が 1 から 3 の範囲 に布置されることが明らかになった。

鈴木らの実験では, 白としての許容率が高い色の範囲は a*值が -1 から 1, b*值が-4 から-7 の領域にあり, 青方向にずれた領域で あったのに対して，本実験による白としての許容率が高い領域は， PB 方向から Y 方向まで b*軸方向に広い範囲となっている. 楕円で 表示した等白色許容率軌跡の領域は, 相関色温度 $3000 \mathrm{~K}$ の照明条件 に比べて相関色温度 $6700 \mathrm{~K}$ の照明条件の方が大きくなり, また, 無 彩色背景条件に比へて, 実空間における有彩色背景条件の方が白 色領域が大きくなることが明らかになった。

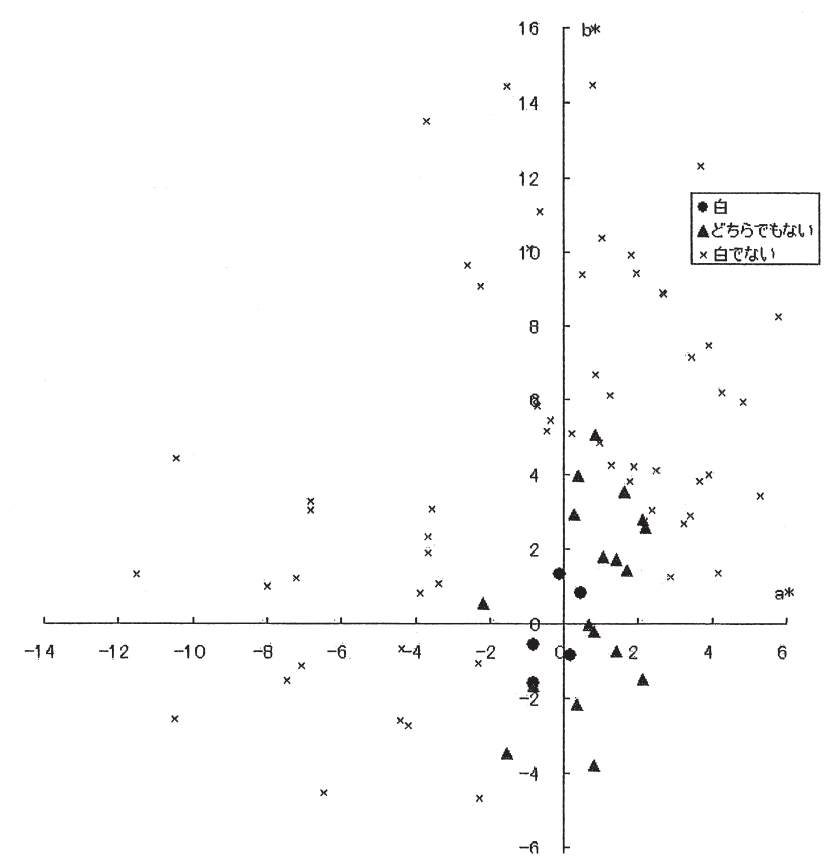

(a)リビング空間

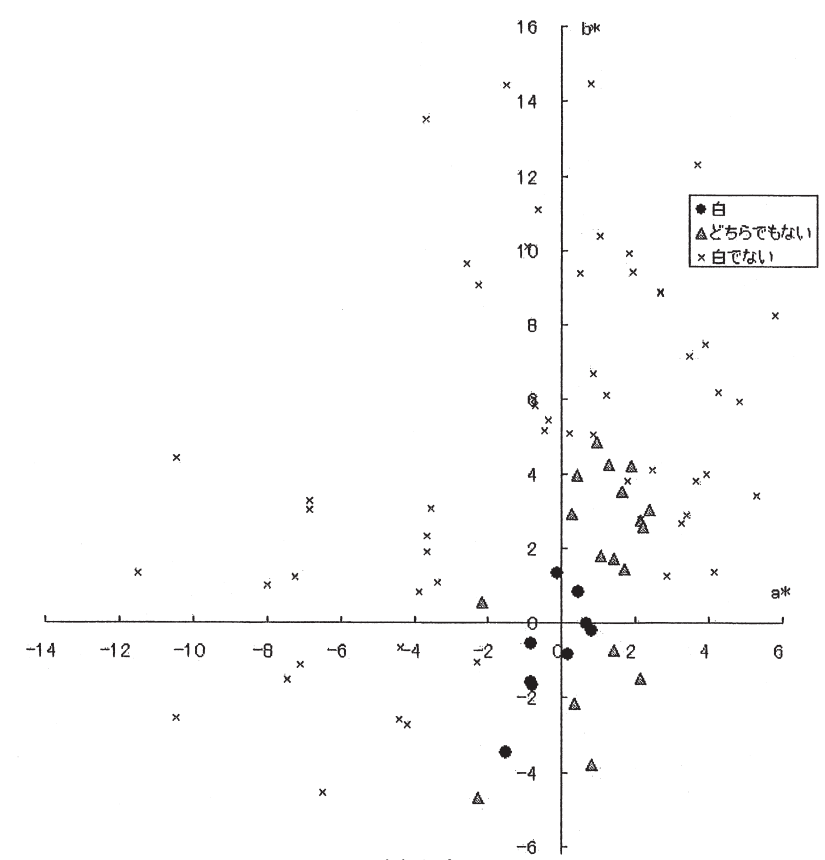

(b) 和室

図 15 相関色温度 $3000 K$ の場合の各色票の白の許容率

Fig.15 The distribution of rate of permissible rate to the perceptual whiteness in the Living room and Japanese room under the fluorescent lamp with the correlated color temperature of 3000K. 


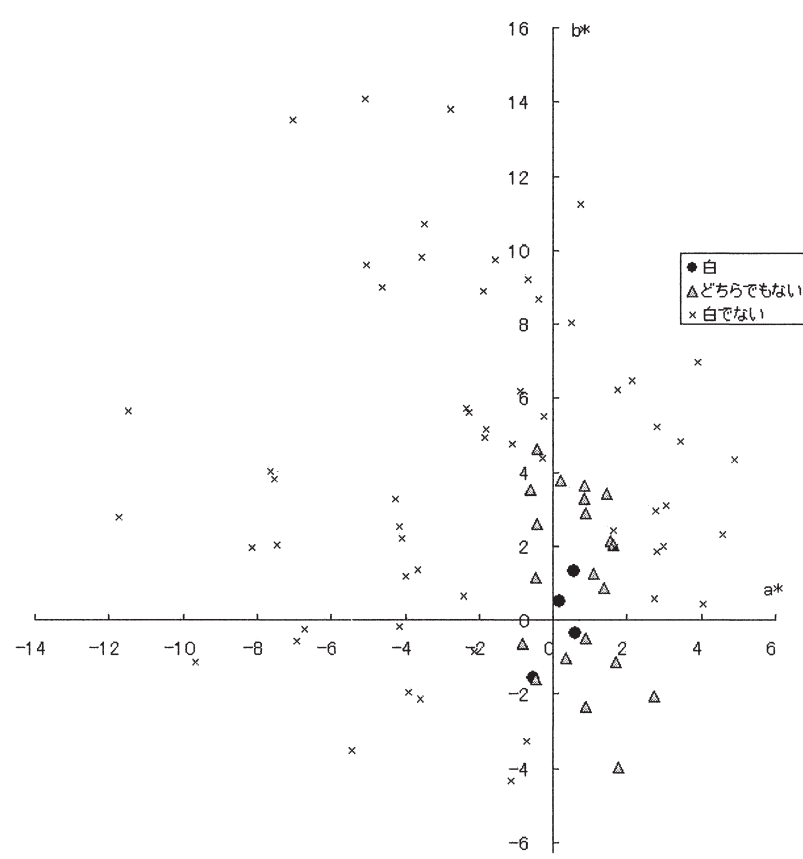

(a)リビング空間

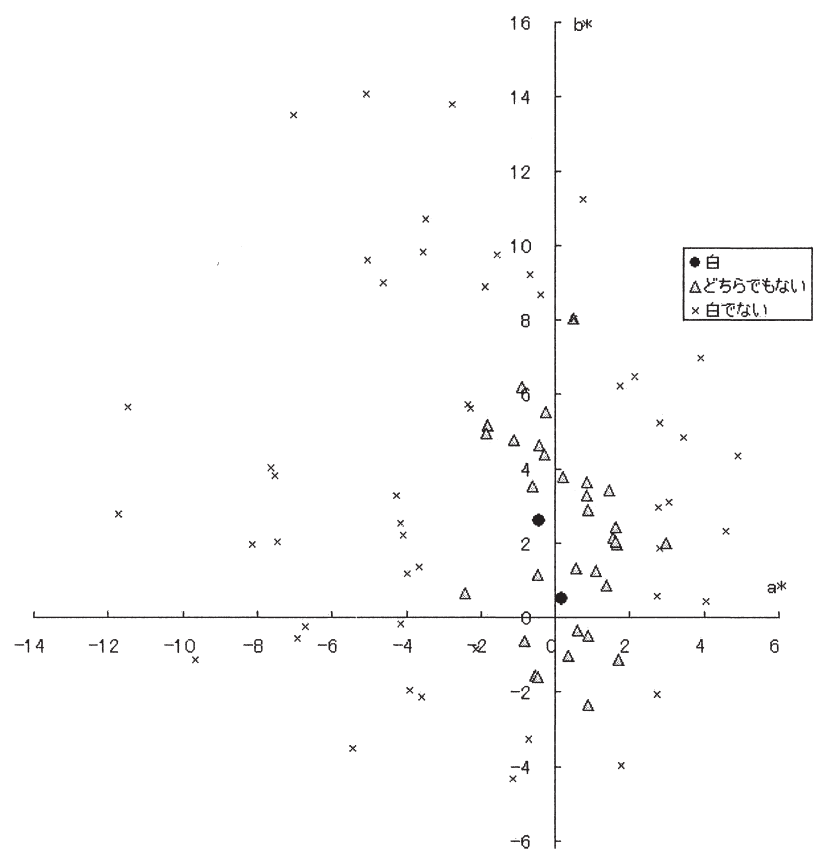

(b) 和室

図 16 相関色温度 $6700 K$ の場合の各色票の白の許容率

Fig.16 The distribution of rate of permissible rate to the perceptual whiteness in the Living room and Japanese room under the fluorescent lamp with the correlated color temperature of $6700 \mathrm{~K}$

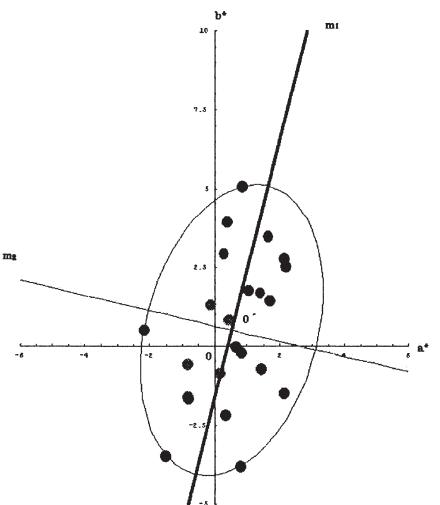

(a) リビング空間

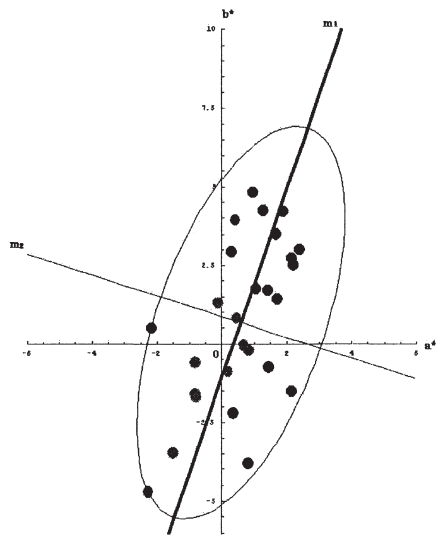

(b) 和室
図 17 相関色温度 $3000 K$ の場合の等白色許容率軌跡

Fig.17 The Locus of the equal perceptual whiteness rate in the Living room and Japanese room under the fluorescent lamp with the correlated color temperature of $3000 \mathrm{~K}$.

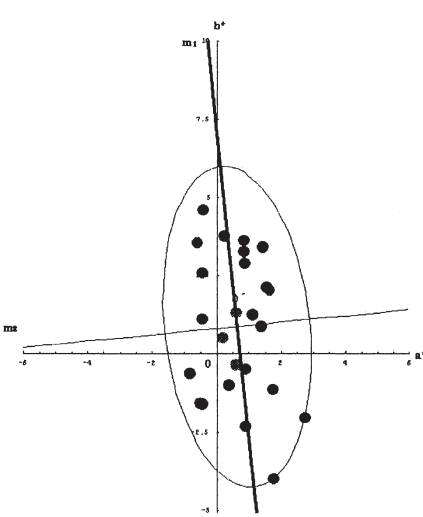

(a) リビング空間

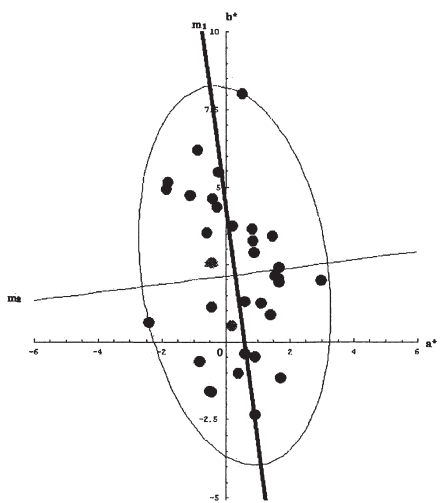

(b) 和室

\section{図 18 相関色温度 $6700 K$ の場合の等白色許容率軌跡}

Fig.18 The Locus of the equal perceptual whiteness rate in the Living room and Japanese room under the fluorescent lamp with the correlated color temperature of $6700 \mathrm{~K}$.

\section{2 白色知覚の定量化の試み}

前述したように, [白]と [どちらでもない]として評価された色票 の色度座標から導いた等白色許容率軌跡の形状は，楕円で表される ことが分かった. また, 色知覚属性值と主観評価結果との対応につ いて検討した結果, クロマ $\mathrm{C}$ おび $\mathrm{a}, \mathrm{b}$ で表される中心座標からの 距離がそれぞれ対応することが明らかになった．そこで，「白色知 覚は, 色みの強さに対応するクロマと色みの方向に関係する」と仮 定して白色知覚の定量化を試みた. CIE1976L*a*b*表色系の $\mathrm{a} *, \mathrm{~b} *$ 座 標の $a *, b * て ゙ も$ 明らかなように, 色度座標の原点からの距離が離れ る色度ほど色みが強くなる. クロマ C が低くなれば，色みの強さが 弱まり, 白色と知覚される割合が高くなることが実験から明らかに なった. また, 色みの方向は知覚される色相を表わし, 色相の違い によって白色知覚が異なることが今回の実験でも明らかになった.

そこで，まず，5.1 で述べた各実験条件での[白]または[どちらで もない] と評価された色票の $\mathrm{a} * \mathrm{~b} *$ 值と中心座標との距離 $\mathrm{r}$ とクロマ $\mathrm{C}$ との対応について検討した. その結果, 両者間の相関係数はきわめ て高いことが分かった. 全ての条件下でもクロマ C と距離 $\mathrm{r}$ との相

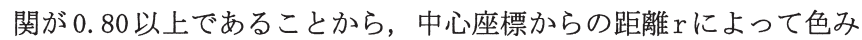
の強さをあらわすこととした，距離 $\mathrm{r}$ が大きい值になれば、その照 
明光下での白色知覚領域が大きくなるを意味しており， 5.1 で述 べた等白色軌跡に囲まれた棛円の面積で推定することができる. 楕円の面積 S は，（1）式で表される.

$$
\begin{aligned}
S=\frac{\alpha}{2} \times \frac{\beta}{2} \times \pi \cdots \cdots \cdots(1) \\
\text { ここで, } \alpha \text { : 等白色許容率軌跡の長軸 } \\
\quad \beta \text { :等白色許容率軌跡の短軸 }
\end{aligned}
$$

(1) 式の $\alpha$ (長軸) と $\beta$ (短軸) は, 等白色許容率軌跡の式を用いて 求めた定数である.

各実験条件で白またはどもらでもないと抽出された色票の密度 を観察すると，(1)式から導出した各条件の楕円の面積 S がほぼ同 じであっても, 図 19 に示すように抽出される色票の密度が異なる ことが分かった. そこで, 白色知覚の抽出率 a を導出し, (2) 式に 示すような楕円体の体積を C とした.

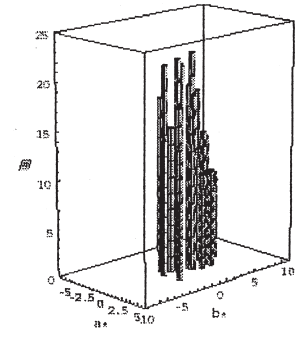

(a) 無彩色背景

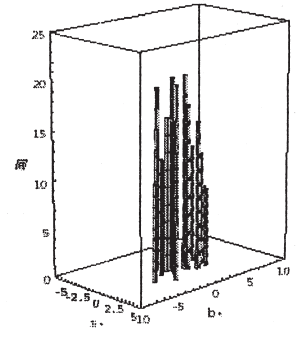

(b) リビング空間

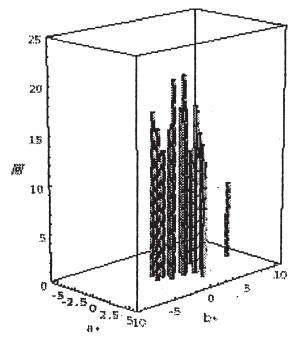

(c) 和室
図 19 各色票の白の許容率と抽出回数のグラフ（相関色温度 6700K） 視点 $\{a *, b *$, 抽出回数 $\}=\{5,-5,2\}$

Fig.19 The distribution of deusity of Perceptual whiteness in the different environmental condition under the fluorescent lamp with the correlated color temperature of $6700 \mathrm{~K}$.

$$
\begin{gathered}
C=\frac{1}{2} \times \frac{4}{3} \times \frac{\alpha}{2} \times \frac{\beta}{2} \times a \times \pi \cdots \cdots \cdots \text { (2) } \\
\text { ここで, } \mathrm{a}: \frac{\text { 実験結果 (抽出回数) }}{\frac{\text { 等白色許容率軌跡の中心 } O \text { から各 } a^{*}, b^{*} \text { 值までの距離 }}{\text { の平均值 }}}
\end{gathered}
$$

(2)式の抽出率 $\mathrm{a}$ は, 図 15 (a) (b), 図 17 (a) (b), 図 18 (a) (b) に 示した相関色温度 $3000 \mathrm{~K}$ と相関色温度 $6700 \mathrm{~K}$ の各照明条件下の等白 色許容率軌跡の内の中心座標 0 - から, [白]と [どちらでもない] 選ばれた色票の色度座標までの距離を $\mathrm{r}^{-}$として, 各色票の $\mathrm{r}$-の 逆数と抽出回数の積を算出し平均值を a とした.

次に, 色みの方向についで検討する. 白色と知覚される色みの 方向は, 実験条件によって異なっている. 図 3, 図 4, 図 7, 図 8 に示した狭帯域発光形蛍光ランプの実験結果より, 相関色温度 3000K では，いずれの実験空間でも3PB 系の色相を白色と多く知覚 し, 相関色温度 $6700 \mathrm{~K}$ では, $10 \mathrm{~PB}$ 系の色相を白色と多く知覚した. このように, 相関色温度の上昇により白色と知覚する色相に推移 が見られたことを明らかにした。 そして, 図 15, 図17, 図18に示 したように, 相関色温度や背景条件によって等白色軌跡の長軸方 向の傾斜角度が異なる. したがって, 傾斜角度を色みの方向に対 応させることとした. さらに，図 19 に示すように，等白色許容率 軌跡を囲む楕円面積が等しくても, 抽出される色票の密度が異な るので，抽出率を考慮して定量化することとした.

そこで，(2)式に色みの方向を表す傾斜角度の変化を加えて楕円 体の体積 C を算出し, これを白色知覚指数 Perceptual Whiteness
Index（PWI）とした.

白色知覚指数 (PWI) $=\frac{1}{2} \times \frac{4}{3} \times \frac{\alpha}{2} \times \frac{\beta}{2} \times \sin \theta \times a \times \pi \cdots \cdots \cdots$ (3) ここで, $1 / 2:$ 楕円体の体積の上半分 (3)式の $\theta$ は, 等白色許容率軌跡の長軸の傾斜角度を表わし, メ トリック色相角を用いて設定した。

$$
\theta=H_{a b}^{\circ}=\tan ^{-1}\left(\frac{b^{*}}{a^{*}}\right) \times \frac{180}{\pi}
$$

（3）式に示すように，白色知覚指数 Perceptual Whiteness Index (PWI) は, 白色知覚領域から導出した楕円の面積 S, 色みの方 向を表す傾斜角度 $\theta$, 抽出率 $\mathrm{a}$ から構成されている. 表 2 に各実験 条件下での白色知覚指数を, また主観評価値と白色知覚指数との 対応は図 20 に示す. 図 20 に示すように, 相関係数 0.80 で高い相 関関係を得ることができた。 なお, 図 9 で示したように, 無彩色背 景下での相関色温度 $3000 \mathrm{~K}$ の場合は, 他の実験条件に比べて抽出 回数が少なくなった. 特に, R, YR, Y 系の色票の抽出回数が少なく なっており, 結果として図 20 に示すように白色知覚指数が小さく なった. 以上のことから, 本実験条件の範囲内で白色知覚の定量 式の妥当性を見出すことができた.

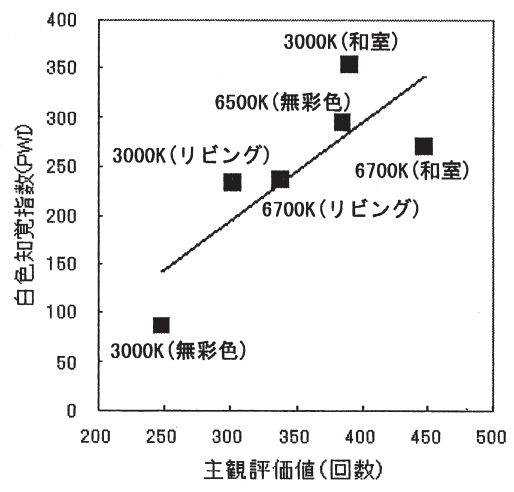

図 20 主観評価結果値と白色知覚指数 (PWI) との対応

Fig.20 Relationship between the experimental results and the

\begin{tabular}{|c|c|c|c|c|c|c|c|}
\hline \multicolumn{2}{|c|}{ 実験空間 } & $\begin{array}{c}\text { 相関色 } \\
\text { 温度 }\end{array}$ & $\begin{array}{c}\alpha \\
(\text { 長軸) }\end{array}$ & $\begin{array}{c}\beta \\
\text { (短軸) }\end{array}$ & $\begin{array}{c}a \\
\text { (抽出率) }\end{array}$ & $\begin{array}{c}\theta \\
\text { (色相角) }\end{array}$ & PWI \\
\hline \multirow{2}{*}{\multicolumn{2}{|c|}{ 無彩色背景 }} & $3000 \mathrm{~K}$ & 3.33 & 3.36 & 9.29 & 0.40 & 87.09 \\
\hline & & $6500 \mathrm{~K}$ & 4.90 & 2.77 & 10.75 & 0.96 & 293.63 \\
\hline \multirow{4}{*}{$\begin{array}{c}\text { 有彩色 } \\
\text { 背景 }\end{array}$} & \multirow{2}{*}{$\begin{array}{l}\text { リビン } \\
\text { グ空間 }\end{array}$} & $3000 \mathrm{~K}$ & 4.67 & 2.64 & 9.84 & 0.92 & 233.44 \\
\hline & & $6700 \mathrm{~K}$ & 5.14 & 2.25 & 10.33 & 0.94 & 235.76 \\
\hline & \multirow{2}{*}{ 和室 } & $3000 \mathrm{~K}$ & 6.52 & 2.59 & 11.22 & 0.89 & 353.43 \\
\hline & & $6700 \mathrm{~K}$ & 6.15 & 2.93 & 7.47 & 0.96 & 270.13 \\
\hline \multicolumn{7}{|c|}{ 相関係数 } & 0.80 \\
\hline
\end{tabular}
Perceptual Whiteness Index.

表 2 係数 $\alpha, \beta, \mathrm{a}, \theta$ と白色知覚指数 (PWI), 主観評価結果値と 白色知覚指数 (PWI) の相関係数

Table 2 Correction of the experimental result and Perceptual Whiteness Index.

\section{6. おわりに}

無彩色背景および実空間を想定した有彩色背景条件下で，相関 色温度の異なる鸴光ランプを用いた白色あるいは近似白色の白色 知覚を検討した. その結果, 1) 相関色温度 $3000 \mathrm{~K}$ の無彩色背景条件 では, 狭帯域発光形蛍光ランプのほうが広帯域発光形蛍光ランプ よりも白と判断する色票の抽出率は高い，2) 相関色温度 $6500 \mathrm{~K}$ の無 彩色背景条件では, 広帯域発光形蛍光ランプのほうが狭帯域発光 
形蛍光ランプよりも白と判断する色票の抽出率は高い，3) 実空間に おける有彩色背景条件では, 無彩色背景条件よりも白と判断する 色票の抽出回数が多い，4）実験結果を基に白の許容率を算出し，楕 円形状で表される等白色許容率軌跡を導出した，5）今回の実験で 得た白色知覚領域から導出した楕円の面積 S, 色みの方向を傾斜角 度 $\theta$, 抽出率 a から, 白色知覚指数 Perceptual Whiteness Index (PWI) 導出した。 6) 白色知覚指数 Perceptual Whiteness Index (PWI) と今回の実験で得た主観評価値との間に高い相関を得 た.

今回の㥶験では，表 2 に示したように，照明光による影響と背景 による影響はそれぞれの係数に含まれているが，個々の影響を分 離してない. 背景による色対比効果の影響についてはさらに検討 する必要がある. また、白色知覚と明るさ知覚との関連性や加齢に よる白色知覚の影響など, 今後の課題として取り組んでいきたい.

\section{参考文献}

(1) JISZ8715 (1991): 白色度一表示方法.

(2) 内田洋子:CIE 白色度式についての一考察, 色学誌, 14-12, pp. 106-113(1990).

(3) 内田洋子: 蛍光増白試料の視感判定と白色度評価に関する研究, pp. 97-119 (1994).

（4）馬場護郎: 白さの定量的評価, 光学, 10-1, pp. 11-17 (1981).

（5）鈴木恒男: 知覚的白さの許容度に基づく白色度, 色学誌, 14-2, pp. 114-121 (1990).

（6）鈴木恒男, 淵田隆義, 小松原仁, 坂田勝亮: 光源色での白色度の研 究, 照学誌, 77-2, pp. 9-12 (1993).

（7）鈴木恒男, 知覚的白さの定量化に関する試み, 色学誌, 23-3, pp. 168-175 (1999).

(8) 片山一郎, 飯山真正, 枡見和考: 照明光の分光組成が知覚白色度 に与える影響, 照学誌, 85-5, pp. 338-345(2001).

(9) 片山一郎, 枡見和考, 青木務: Chromatic Strength と知覚白色度 の関係, 照学誌, 86-5, pp. 286-291 (2002).

(10) M. Ayama, T. Akatsu, E. Toriumi, K. Mukai and S. Kanaya: Whiteness Perception under Different Types of Fluorescent Lamps, Color Res. App1.28, pp. 96-102 (2003).

（11）舘祐二, 金谷末子, 阿山みよし, 向健二:種々の照明光下におけ る白色領域に関寸る検討, 第 32 回照明学会全国大会予稿集 (1999).

（12）舘祐二, 金谷末子, 阿山みよし, 向健二:有彩色背景下における 白色感に関する検討, 第 34 回照明学会全国大会予稿集 (2001) ,

(13) S. Kanaya, M. Ayama, L. Halonen, M. Eloholma and K. Mukai : A comparative study of whiteness perception in Japan and Finland, International Lighting Congress 2001 Proceeding, pp. 427-432(2001).

（14）江田哲也, 阿山みよし, 金谷末子, 向健二: 電球色及び昼光色蛍 光灯照明下に打ける知覚的白色領域, 照学 誌, 89-2, pp. 91-99 (2005).

（受付日 2005 年 2 月 25 日/採録日 2005 年 6 月 3 日）

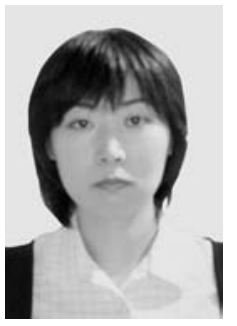

太田 亜紀子（正会員）

日立物流ソフトウェア株式会社

厂140-0013

東京都品川区南大井 6-26-1

1980 年生まれ. 2003 年 3 月金沢工業大学工学 部経営工学科卒業, 2005 月 3 月金沢工業大学 大学院工学研究科博士課程前期システム設計 工学専攻修了．同年 4 月日立物流ソフトウェ ア株式会社に入社. 照明学会会員.

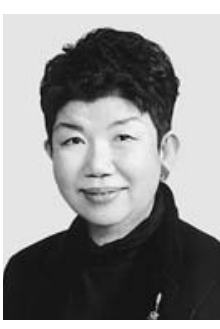

金谷 末子（専門会員）

金沢工業大学

環境・建築学部建築都市デザイン学科

T921-8812

石川県石川郡野々市町扇が丘 7-1

1939 年生まれ. 1962 年同志社大学工学部電気

工学科卒業. 同年松下電器産業株式会社に入

社, 照明研究所に配属. 1998 年金沢工業大学 教授. 博士 (工学)。現在, 同大学 環境·建築学部建築都市デザイ ン学科で光環境の評価, 加歯と光環境, 景観照明等の研究と教 育に従事。照明学会理事(1995-1997), 日本照明委員会副会長 (2003-), 1998 年照明学会賞, 2003 年 CIE Award 受賞. 照明学会, 日 本照明委員会, 日本建築学会, 日本色彩学会, 日本人間工学会, 日 本視覚学会·各会員.

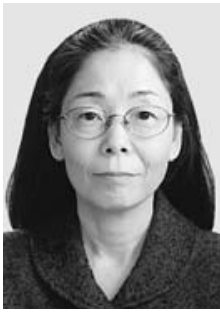

阿山 みよし（専門会員）

宇都宮大学大学院工学研究科

情報制御システム科学専攻

† 321-0904

杤木県宇都宮市陽東 7-1-2

1954 年生まれ. 1983 年東京工業大学院総合理 工学研究科物理情報工学専攻博士課程修了.

宇都宮大学工学部助教授を経て現在大学院工 学研究科教授. 工学博士. 視覚情報処理, 色彩科学, 視聴覚相 互作用, 自動車運転者の視覚認知特性の研究と教育に従事. 照 明学会, 日本照明委員会, 日本視覚学会, 応用物理学会, 日本 光学会, 日本色彩学会, 映像情報メディア学会 各会員.

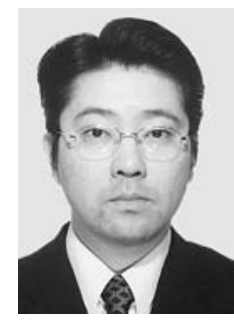

向 健二（正会員）

松下電器産業株式会社 照明社

于569-1143

大阪府高槻市幸町 $1-1$

1967 年生まれ. 1992 年 3 月大阪大学大学院工 学研究科建築工学専攻博士前期課程修了. 同

年 4 月松下電器産業株式会社に入社. 現在, 照明社 LED 事業化推進グループにおいて照明 用白色 LED モジュールの開発に従事. 照明学会, 日本照明委員 会, 日本建築学会 各会員. 